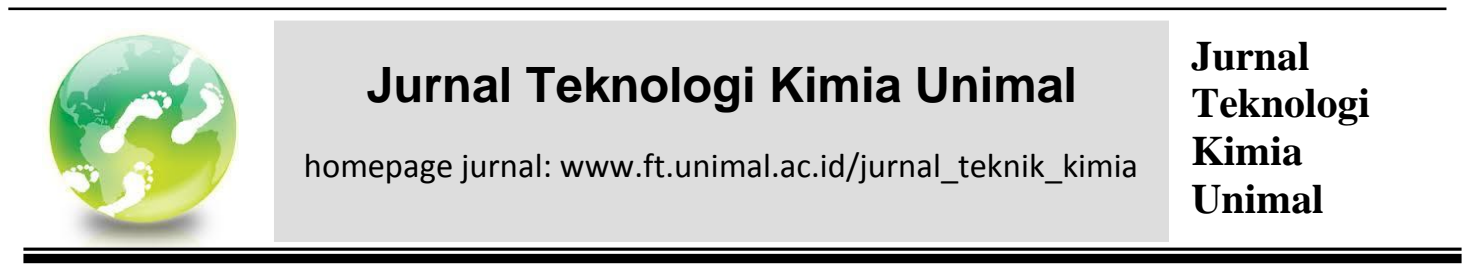

\title{
Produksi Minyak Alpukat dari Daging Buah Alpukat Gayo Dengan Metode Ekstraksi Menggunakan Pelarut N-Heksan Untuk Aplikasi dalam Sabun Mandi Herbal
}

\author{
Zainuddin Ginting, Lukman Nurhakim, Lukman Hakim \\ Jurusan Teknik Kimia Universitas Malikussaleh, Kampus Bukit Indah Lhokseumawe \\ Coresponden: 01.lukman.nuhakim@gmail.com
}

\begin{abstract}
Abstrak. Extraction is a process of separating a substance based on its different solubility to two different insoluble liquids. The method used in this study is the soxhlet extraction method with n-hexane solvent. The method of extracting lost oil in the process is less, so that more oil is produced. This study aims to determine the effect of extraction time and temperature on the process of extracting avocado oil which produces good characteristics of avocado oil and the composition of avocado oil fatty acids and the application of oil in the manufacture of herbal bath soap. The extraction process was carried out at a temperature variation of $75^{\circ} \mathrm{C}, 80^{\circ} \mathrm{C}$ and $85^{\circ} \mathrm{C}$ with a variation of time of 120 minutes, 180 minutes, and 240 minutes. Avocado oil produced in this study has the characteristics of a blackish green oil color, with a yield of $46.72 \%$, a specific gravity of $0.91 \mathrm{gr} / \mathrm{ml}$, free fatty acids $1.64 \%$, and a saponification number of $172.5 \mathrm{mgKOH} /$ oil. The results of analysis using Gas Chromatoghraphy-Mass Spectrocopy (GC-MS) found that the amount of fatty acids making up avocado oil triglycerides in this study were oleic acid (31.43\%), palmitic acid (25.79\%), and linoleic acid ( $8.39 \%)$. So that avocado oil is included in the olein-palmito-linolein group. The results of the analysis of avocado oil applications in the manufacture of herbal bath soaps have characteristics of water content of $14.4 \%$, free fatty acids $2.03 \%$, free alkaline $0 \%$, and $\mathrm{pH}$ values of 9.46 .
\end{abstract}

Kata kunci: Avocado oil, Extraction, N-Hexane, Herbal Bath Soap.

Abstrak. Ekstraksi adalah suatu proses pemisahan suatu zat berdasarkan perbedaan kelarutannya terhadap dua cairan tidak saling larut yang berbeda. Adapun metode yang digunakan pada penelitian ini adalah metode ekstraksi soklet dengan pelarut n-heksana. Dengan metode ekstraksi kehilangan minyak dalam proses lebih sedikit, sehingga minyak yang dihasilkan lebih banyak. Penelitian ini bertujuan yaitu untuk mengetahui pengaruh waktu dan suhu ekstraksi pada proses pengambilan minyak alpukat yang menghasilkan karakteristik minyak alpukat yang baik dan komposisi asam lemak minyak alpukat serta pengaplikasian minyak dalam pembuatan sabun mandi herbal. Proses ekstraksi dilakukan pada variasi suhu $75^{\circ} \mathrm{C}, 80^{\circ} \mathrm{C}$, dan $85^{\circ} \mathrm{C}$ dengan variasi waktu 120 menit, 180 menit, dan 240 menit. Minyak alpukat yang dihasilkan dalam penelitian ini memiliki karakteristik warna minyak hijau kehitaman, dengan yield sebesar $46,72 \%$, berat jenis $0,91 \mathrm{gr} / \mathrm{ml}$, asam lemak bebas $1,64 \%$, dan bilangan penyabunan $172,5 \mathrm{mgKOH} / \mathrm{minyak}$. Hasil analisa dengan menggunakan Gas Chromatoghraphy-Mass Spectrocopy (GC-MS) diketahui bahwa jumlah komponen asam lemak penyusun trigliserida minyak alpukat pada 
penelitian ini yaitu asam oleat $(31,43 \%)$, asam palmitat $(25,79 \%)$, dan asam linoleat $(8,39 \%)$. Sehingga minyak alpukat termasuk dalam golongan olein-palmito-linolein. Hasil analisa aplikasi minyak alpukat dalam pembuatan sabun mandi herbal memiliki karakteristik kadar air sebesar 14,4\%, asam lemak bebas 2,03\%, alkali bebas $0 \%$, dan nilai $\mathrm{pH}$ sebesar 9,46.

Kata kunci: Minyak Alpukat, Ekstraksi, N-Heksan, Sabun Mandi Herbal.

\section{Pendahuluan}

Negara Republik Indonesia yang sangat luas dengan menghasilkan banyak buahbuahan menurut daerah tertentu, khususnya di propinsi Aceh, kabupaten Aceh Tengah, Takengon yang merupakan daerah dataran tinggi. Alpukat (Persea americana L) merupakan salah satu komoditas buah yang telah meningkat di Kabupaten Aceh Tengah. Tanaman yang aslinya bermula dari Amerika Latin ini banyak dijumpai dicelah kebun kopi yang ada di daerah ini. Pemanfaatan buah alpukat dalam masyarakat digunakan sebagai jus pelepas dahaga dan minimnya minat untuk digunakan sebagai sediaan kosmetik yang lebih bernilai. Dalam lingkup pasar minyak dan lemak saat ini minyak alpukat dikenal sebagai minyak pendatang baru. Akan tetapi tidak banyak negara yang aktif dalam produksi minyak alpukat ini, seperti Meksiko (34\%), USA (8\%), Afrika Selatan $(<2 \%)$, dan Selandia Baru $(<1 \%)$. Negara-negara ini juga aktif dalam pengembangbiakan dan perdagangan buahnya. Minyak alpukat tidak hanya digemari karena rasanya yang enak, namun juga karena khasiatnya dalam kesehatan (Litz et al., 2007).

Minyak alpukat merupakan minyak pangan (edible oil) yang dapat diperoleh dengan berbagai cara seperti Soxhletasi (Banat et al., 2013), pengepresan dingin (coldpressing) (Mostert et al., 2007), dan perkolasi serbuk daging buah (Kalia et al., 2002). Pelarut yang umum digunakan dalam ekstraksi minyak adalah $n$-heksana, petroleum eter maupun benzena. Proses evaporasi selanjutnya diperlukan untuk memisahkan minyak alpukat dengan pelarutnya (Bora et al., 2001). Kandungan minyak buah alpukat berkisar antara 8-30\% tergantung pada varietas dan kondisi tumbuh (Takenaga et al., 2008).

Berdasarkan hasil penelitian Zulharmita, dkk (2013) yang telah melakukan ekstraksi asam lemak dari daging alpukat solok menggunakan pelarut n-hexan dengan sampel buah alpukat dipisah menjadi dua kelompok yaitu kelompok A diperam 3 hari dan kelompok B diperam 5 hari. Hasil yang diperoleh yaitu berat minyak kelompok A: 149,274 g dan kelompok B: 169,598 g. Dari hasil Analisa menggunakan Gas Chromatography-Mass Spectrocopy (GC-MS) diketahui bahwa komposisi asam lemak pada sampel A yaitu asam miristat $(2,44 \%)$, asam behenat $(2,22 \%)$, asam isopalmitat $(10,97 \%)$ dan komposisi asam lemak pada sampel B yaitu nonanoat $(1,2 \%)$, asam miristat $(2,8 \%)$, asam behenat $(2,23 \%)$, asam palmitoleainat $(7,91 \%)$, asam linoleat $(10,95 \%)$, asam oleat $(28,69 \%)$, dan asam isopalmitat $(4,77 \%)$.

Penelitian yang dilakukan oleh Saputra, dkk (2017) yang telah melakukan pengaruh persiapan bahan baku dan suhu ektraksi pada ekstraksi asam lemak dari daging alpukat solok menggunakan pelarut n-hexan dengan sampel buah alpukat matang. Hasil yang diperoleh rendemen sebesar $66 \%$ dari berat kering dan minyak alpukat memiliki indeks bias 1,452 , berat jenis $0,8963 \mathrm{~g} / \mathrm{mL}$, bilangan asam $2,36 \mathrm{mg} \mathrm{KOH} / \mathrm{g}$ minyak, bilangan peroksida 29,75 mek $\mathrm{O}_{2} / 1000 \mathrm{~g}$ minyak, bilangan iodium 65,01 g I $2 / 100 \mathrm{~g}$ minyak, dan bilangan penyabunan $88,56 \mathrm{mg} \mathrm{KOH} / \mathrm{g}$ minyak serta komposisi asam lemak yaitu asam kaprilat $(0,92 \%)$, asam laurat $(9,41 \%)$, asam miristat $(2,8 \%)$, asam palmitat $(14,44 \%)$, asam palmitoleat $(0,84 \%)$, asam linoleat $(1,36 \%)$, dan asam oleat $(14,81 \%)$. 
Berdasarkan hal tersebut dilakukan penelitian untuk mengetahui karakteristik dan komposisi asam lemak dari minyak alpukat dan diaplikasikan dalam pembuatan sabun mandi herbal.

\section{Metodologi}

Bahan yang digunakan pada penelitian ini adalah alpukat Gayo, N-heksana, Aquadest, Alkohol 90\% netral, KOH 0,1 N, KOH alkohol 0,5 N, Fenolftalein dan $\mathrm{HCl}$ $0,5 \mathrm{~N}$. Metode yang digunakan ada tiga tahap. Tahap pertama persiapan bahan baku, tahap kedua ekstraksi dan tahap ketiga analisa.

Tahap persiapan bahan baku dilakukan dengan cara pengecilan ukuran dan pengeringan. Dilakukan pengecilan ukuran terhadap daging buah alpukat segar dengan menggunakan blender sehingga menjadi bubur ( $p u l p)$. Tujuan proses pengecilan ukuran daging alpukat untuk mempermudah pengeringan dan memperluas permukaan bahan saat dilakukan proses ekstraksi. Selanjutnya, pulp yang telah halus dilanjutkan dengan proses pengeringan yaitu menggunakan pengeringan oven dengan suhu berkisar antara $60^{\circ} \mathrm{C}$, lama pengeringan ini dilakukan 2 hari.

Proses ekstraksi yang digunakan yaitu ekstraksi dengan pelarut (Solvent). Pelarut digunakan yaitu n-heksan dan alat ekstraksi yang digunakan adalah perangkat Soxhlet. Sebelum dimasukkan ke dalam tabung ekstraksi Soxhlet, pulp yang telah kering diiris kecil dan dibungkus dengan kertas saring. Suhu dan waktu ekstraksi dipertahankan sesuai variabel bebas. Selanjutnya pelarut di distilasi pada suhu $80^{\circ} \mathrm{C}$ hingga terpisah dari minyak hasil ekstraksi. Sampel minyak dihitung beratnya untuk menentukan rendemen minyak yang diperoleh.

Variabel tetap yang digunakan adalah berat daging alpukat 50 gram, volume pelarut $200 \mathrm{ml}$, suhu pengeringan buah alpukat dalam oven $60^{\circ} \mathrm{C}$, waktu pengeringannya 2 hari. Variabel bebas yang digunakan adalah waktu ekstraksi (120, 180, dan 240) menit dan suhu ekstraksi $(75,80 \text {, dan } 85)^{\circ} \mathrm{C}$. Variabel terikat yang digunakan adalah yield (\%), berat jenis, analisa asam lemak bebas, analisa angka penyabunan, dan analisa komponen kimia dengan alat GC-MS.

\section{Hasil dan pembahasan}

\subsection{Analisa Yield}

Adapun grafik hubungan pengaruh antara suhu dan waktu ekstraksi terhadap yield dapat dilihat pada Gambar 4.1.

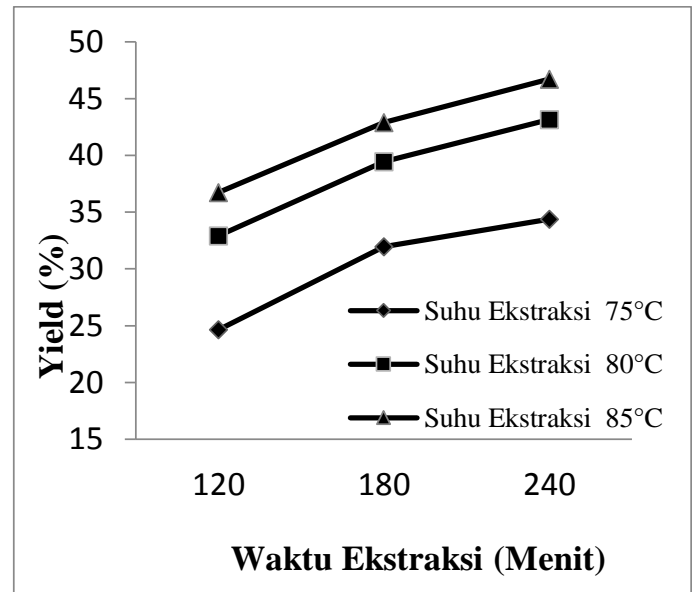

Gambar 4.1 Pengaruh Suhu dan Waktu Ekstraksi Terhadap Yield 
Dari Gambar 4.1 dapat dilihat bahwa semakin lama waktu ekstraksi yield minyak alpukat yang dihasilkan akan semakin meningkat. Hal ini disebabkan karena waktu kontak antara pelarut dengan bahan yang akan diekstrak semakin lama, dan laju difusi pelarut kedalam padatan menjadi lebih besar serta sirkulasi yang terjadi semakin banyak menyebabkan yield minyak alpukat yang dihasilkan juga semakin besar.

Selain itu, dapat dilihat bahwa semakin tinggi suhu ekstraksi maka yield minyak alpukat yang didapat semakin tinggi. Hal ini disebabkan oleh kenaikan suhu dapat menyebabkan gerakan molekul pelarut semakin cepat dan acak. Kenaikan suhu menyebabkan pori-pori padatan mengembang sehingga memudahkan pelarut untuk mendifusi masuk ke dalam pori-pori padatan dan melarutkan minyak alpukat. Oleh karena itu, minyak alpukat yang berinteraksi semakin besar dan menyebabkan terjadinya perpindahan massa dari padatan umpan menuju pelarut semakin besar. Sehingga dengan bertambahnya suhu ekstraksi, maka minyak alpukat yang dapat terekstrak akan semakin banyak. Dari Gambar 4.1 juga dapat dilihat yield minyak alpukat yang didapat berkisar antara $24,64 \%-46,72 \%$. Yield minyak yang tertinggi diperoleh sebesar $46,72 \%$ dengan suhu dan waktu ekstraksi yaitu $85^{\circ} \mathrm{C}$ dan 240 menit dan terendah diperoleh sebesar $24,64 \%$ dengan suhu dan waktu ekstraksi yaitu $75^{\circ} \mathrm{C}$ dan 120 menit.

\subsection{Analisa Densitas}

Adapun grafik hubungan pengaruh antara suhu dan waktu ekstraksi terhadap densitas dapat dilihat pada Gambar 4.2.

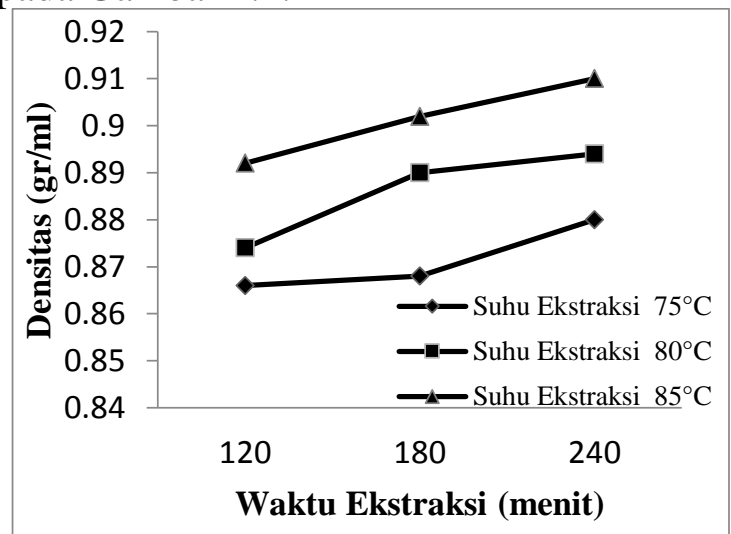

Gambar 4.2 Pengaruh Suhu dan Waktu Ekstraksi Terhadap Densitas

Dari Gambar 4.2 dapat dilihat bahwa berat jenis minyak meningkat seiring dengan peningkatan waktu ekstraksi, karena komponen-komponen yang mempunyai titik didih tinggi membutuhkan waktu yang lebih lama untuk terdistilasi jika dibandingkan dengan komponen-komponen bertitik didih rendah. Semakin lama waktu ekstraksi maka akan terjadi peningkatan konsentrasi minyak yang disebabkan oleh semakin banyaknya akumulasi komponen-komponen kimia penyusun minyak, baik itu senyawa yang bertitik didih tinggi maupun bertitik didih rendah.

Gambar 4.2 juga dapat dilihat semakin tinggi suhu maka densitas yang didapat semakin tinggi. Hal ini dikarenakan peningkatan suhu yang meningkat akan menghasilkan reaksi oksidasi termal yang diakibatkan pengaruh panas yang dihasilkan sehingga membuat semakin merenggang molekul-molekul dalam minyak dan ikatan antar molekul semakin kecil, Pada penelitian ini nilai densitas yang diperoleh antara 0,866-0,91 gr/ml. Hasil terbaik yang didapatkan adalah pada suhu ekstraksi $85^{\circ} \mathrm{C}$ dengan waktu ekstraksi 240 menit, dimana densitas minyak yang dihasilkan yaitu $0,91 \mathrm{gr} / \mathrm{ml}$.

\subsection{Analisa Asam Lemak Bebas}


Adapun grafik hubungan pengaruh antara suhu dan waktu ekstraksi terhadap asam lemak bebas dapat dilihat pada Gambar 4.3.

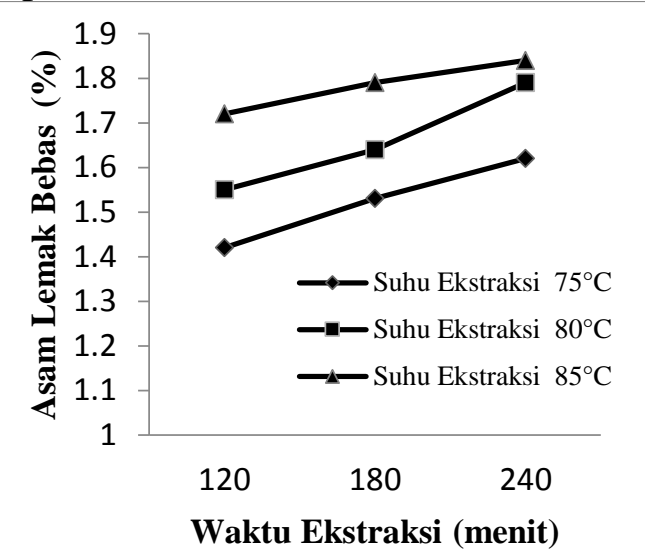

Gambar 4.3 Pengaruh Suhu dan Waktu Ekstraksi Terhadap Asam Lemak Bebas

Berdasarkan dari Gambar 4.3 dapat menunjukkan bahwa meningkatnya asam lemak bebas berbanding lurus dengan kenaikan suhu. Selama proses ekstraksi, minyak dan lemak dapat terhidrolisis oleh air dan suhu yang digunakan selama proses ekstraksi dapat mengakibatkan minyak terurai menjadi asam lemak bebas karena minyak merupakan trigliserida. Pada Gambar 4.3 dapat dilihat bahwa asam lemak bebas minyak alpukat meningkat seiring dengan peningkatan waktu ekstraksi. Semakin lama waktu ekstraksi maka akan terjadi peningkatan terhadap asam lemak bebas minyak yang disebabkan oleh semakin banyaknya akumulasi komponen-komponen kimia penyusun minyak dan peruraian dari gliserida sehingga dapat terjadi pembentukan asam lemak bebas.

Kadar asam lemak bebas (\%ALB) yang dibolehkan dalam minyak alpukat adalah maksimal 3\%. Pada penelitan ini dengan suhu ekstraksi $75^{\circ} \mathrm{C}$ dan waktu ekstraksi 120 menit adalah kadar asam lemak bebas yang terbaik dihasilkan yaitu 1,18\%. Dan dengan suhu serta waktu ekstraksi yang lain kadar asam lemak bebas juga berada dibawah 3\% sehingga masih memenuhi standar mutu minyak berdasarkan Gracefruit Ltd. Dari gambar 4.3 dapat dijelaskan bahwa suhu dan waktu ekstraksi mempengaruhi kadar asam lemak bebas yang terkandung dalam minyak alpukat yang dihasilkan.

\subsection{Analisa Bilangan Penyabunan}

Adapun grafik hubungan pengaruh antara suhu dan waktu ekstraksi terhadap bilangan penyabunan dapat dilihat pada Gambar 4.4.

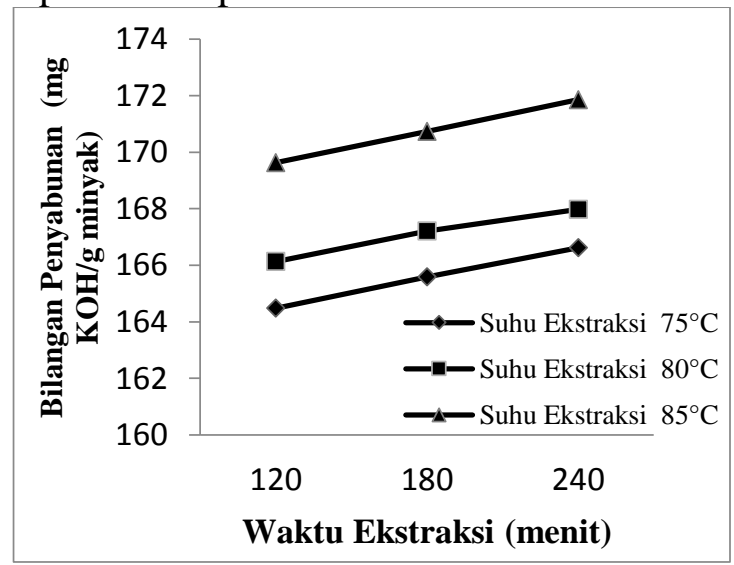




\section{Gambar 4.4 Pengaruh Suhu dan Waktu Ekstraksi Terhadap Bilangan Penyabunan}

Berdasarkan dari Gambar 4.4 dapat menunjukkan bahwa meningkatnya bilangan penyabunan berbanding lurus dengan kenaikan suhu. Tingginya bilangan asam pada minyak alpukat disebabkan oleh suhu pada proses ekstraksi menyebabkan terjadinya pemutusan rantai karbon pada minyak yang mengakibatkan berkurangnya bobot molekul minyak alpukat sehingga bilangan penyabunan meningkat. Pada Gambar 4.4 dapat dilihat bahwa bilangan penyabunan minyak alpukat meningkat seiring dengan peningkatan waktu ekstraksi. Semakin lama waktu ekstraksi maka akan terjadi peningkatan terhadap bilangan penyabunan minyak yang disebabkan oleh terputusnya molekul-molekul asam lemak yang terdapat dalam minyak sehingga berat molekul minyak alpukat akan menjadi kecil sehingga bilangan penyabunan yang diperoleh semakin besar.

Dari gambar di atas dapat disimpulkan bahwa peningkatan suhu dan lamanya waktu ekstraksi mempengaruhi bilangan penyabunan. Menurut Ketaren (1986) tinggi rendahnya bilangan penyabunan dipengaruhi oleh berat molekul minyak. Minyak yang disusun oleh asam lemak berantai pendek berarti memiliki berat molekul rendah maka akan mempunyai bilangan penyabunan yang relatif tinggi. Selain itu hal yang menyebabkan berbedanya bilangan penyabunan adalah dari faktor budidaya, yaitu tempat tumbuh, iklim, musim, waktu panen, faktor genetik lainnya serta proses ekstraksi minyak. Bilangan penyabunan tertinggi pada suhu ekstraksi $85^{\circ} \mathrm{C}$ dengan waktu ekstraksi 240 menit yaitu sebesar $172,5 \mathrm{mg} \mathrm{KOH} / \mathrm{g}$ dan angka penyabunan terendah pada suhu ekstraksi $75^{\circ} \mathrm{C}$ dengan waktu ekstraksi 120 menit yaitu $164,1 \mathrm{mg} \mathrm{KOH} / \mathrm{g}$. Bilangan penyabunan minyak alpukat yang didapatkan pada penelitian ini memiliki nilai yang tidak jauh berbeda dengan nilai bilangan minyak alpukat menurut Gracefruit Ltd yang berada pada rentan 187-197 mg KOH/g, bilangan penyabunan setiap minyak berbeda-beda dan tidak pernah sama.

\subsection{Analisa GC-MS}

Minyak yang dianalisis dengan GC-MS adalah minyak hasil ekstraksi dengan suhu ekstraksi $85{ }^{\circ} \mathrm{C}$ dengan waktu ekstraksi 240 menit. Data hasil analisa GC-MS minyak alpukat ditunjukkan pada gambar 4.5.

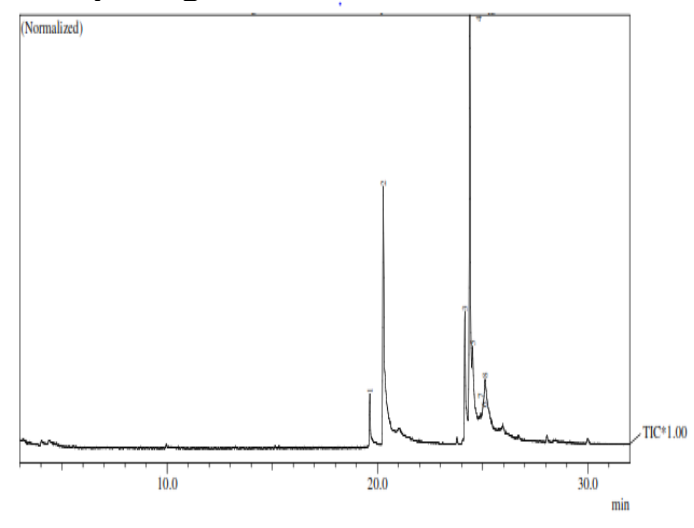

Peak Report TIC

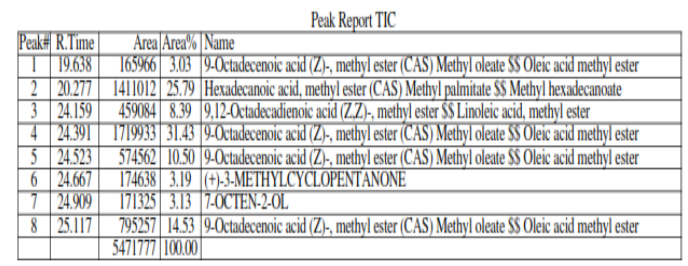

Gambar 4.5. Kromatogram Minyak Alpukat dengan Pelarut N-Heksana 
Analisa dengan menggunakan Gas Chromatoghraphy Mass Spectrometry (GCMS) bertujuan untuk mengetahui senyawa yang terkandung didalam metil ester minyak dari minyak alpukat. Analisa dengan menggunakan GC-MS menghasilkan puncakpuncak spektra yang menunjukkan jenis senyawa yang spesifik. Suatu senyawa dikatakan mirip dengan senyawa standar apabila memiliki berat molekul yang sama, pola fragmen yang mirip, dan harga SI (indeks kemiripan) yang tinggi. Berdasarkan pada gambar 4.5 kromatogram menunjukkan adanya 5 senyawa dalam minyak alpukat dan 3 diantaranya merupakan senyawa yang dominan. Dan tiga komponen senyawa yang paling dominan secara berturut-berturut dimulai dari asam oleat, asam palmitat, dan asam linoleat dengan masing-masing area sebesar 31,43\%, 25,79\% dan 8,39\%. Sehingga minyak alpukat termasuk dalam golongan olein-palmito-linolein.

\subsection{Aplikasi Minyak Alpukat}

Pada aplikasi minyak alpukat dalam pembuatan sabun mandi diuji karakteristik sabun yang dilakukan mengacu kepada SNI 06-3532-1994 dan kemudian dibandingkan hasil yang diperoleh dengan syarat mutu sabun. Hasil karakterisasi yang diperoleh ditunjukan dalam Tabel 4.2. Berdasarkan SNI maksimal kadar air yang terdapat dalam sabun mandi adalah 15\%. Pada penelitian ini sabun memiliki kadar air sebesar 14,4\%. Walaupun mempunyai kadar air yang tinggi, sabun tersebut memiliki tekstur yang sedikit lunak. Tekstur sabun yang lunak dapat disebabkan oleh kandungan asam lemak yang terdapat pada minyak yang dihasilkan. Dalam penelitian ini, tidak ditemukan kadar alkali bebas pada sabun setelah penyimpanan setelah 2 minggu. Hal ini ditandai dengan tidak terbentuknya warna merah muda pada saat larutan sampel ditetesi dengan indikator phenolphthalein. Asam lemak bebas berpengaruh terhadap buih yang dihasilkan serta perubahan $\mathrm{pH}$ yang terjadi. Nilai asam lemak bebas berbanding terbalik terhadap nilai alkali bebas dimana jika nilai asam lemak bebas yang terkandung dalam sabun bernilai negatif maka sabun akan mengandung alkali bebas.

Pengujian alkali bebas bertujuan untuk mengetahui jumlah alkali yang tidak berikatan dengan minyak. Keberadaan alkali bebas pada sabun akan berpengaruh terhadap keamanan kulit ketika sabun digunakan. Hal tersebut dikarenakan reaksi basa yang terjadi pada sabun dapat meyebabkan iritasi pada kulit. Uji iritasi dilakukan untuk melihat keamanan sedian sabun sebelum digunakan dan untuk mengetahui respon kulit manusia terhadap sabun minyak alpukat. Pada penelitian kulit sukarelawan tidak mengalami gejala iritasi seperti timbulnya warna merah dan gatal, sehingga sabun aman untuk digunakan. Sabun yang terbuat dari alkali kuat seperti $\mathrm{NaOH}$ atau KOH mempunyai nilai pH 9,0-10,8 (Gusviputri, dkk., 2013). Jika dilihat dari hasil analisis menunjukkan $\mathrm{pH}$ pada sabun padat sebesar 9,46. Sabun dengan $\mathrm{pH}$ yang terlalu basa dapat meningkatkan daya absorbsi kulit sehingga kulit menjadi iritasi seperti luka, gatal atau mengelupas, dan dapat menyebabkan kulit kering (Wasiatmadja dalam Sari, dkk., 2010).

\section{Kesimpulan}

1. Suhu dan lama waktu ekstraksi sangat mempengaruhi jumlah yield yang dihasilkan, densitas, asam lemak bebas, dan bilangan penyabunan. Semakin tinggi suhu dan lama waktu ekstraksi maka jumlah yield, densitas, asam lemak bebas, dan bilangan penyabunan yang didapat semakin tinggi.

2. Pada ekstraksi minyak alpukat yang diperoleh dengan cara ekstraksi soklet menggunakan pelarut $n$-heksana dihasilkan minyak dengan warna hijau kehitaman 
dengan yield tertinggi dihasilkan dari ekstraksi minyak alpukat sebesar 46,72\% pada suhu dan waktu ekstraksi yaitu $85^{\circ} \mathrm{C}$ dan 240 menit.

3. Dari hasil analisa secara fisika dan kimia, minyak alpukat yang mendekati standar mutu minyak alpukat berdasarkan Gracefruit Ltd yaitu pada suhu $85^{\circ} \mathrm{C}$ dan lama waktu ekstraksi 240 menit yang memiliki berat jenis sebesar $0,91 \mathrm{gr} / \mathrm{ml}$, asam lemak bebas sebesar 1,84\%, dan angka penyabunan sebesar 172,5 mgKOH/g.

4. Komposisi asam lemak penyusun trigliserida minyak alpukat adalah asam oleat $(31,43 \%)$, asam palmitat $(25,79 \%)$, dan asam linoleat $(8,39 \%)$. Sehingga minyak alpukat termasuk dalam golongan olein-palmito-linolein.

5. Aplikasi minyak alpukat dalam pembuatan sabun mandi memiliki karakteristik yang sesuai dengan standar mutu sabun yaitu kadar air sebesar 14,4\%, asam lemak bebas sebesar 2,03\%, kadar alkali bebas sebesar $0 \%$, dan $\mathrm{pH}$ pada sabun sebesar 9,46 .

\section{Daftar Pustaka}

Achmad, R. 2004. Kimia Lingkungan. Edisi 1. Yogyakarta. Andi Offset. hlm. 15-16

Alvarenga, N., \& Ferro, E. A. (2005). Bioactive triterpenes and related compounds from celastraceae. Bioactive Natural Products (Part K), 30, 635-702.

Apriyantono, Anton. 2008. "Lampiran Keputusan Menteri Pertanian".http://varitas.net/dbvarietas/deskripsi/2990.pdf diakses 19 Januari 2019.

Banat, F., Pal, P., Jwaied, N. and Al Rabadi, A., 2013, Extraction of olive oil from olive cake using Soxhlet apparatus, American Journal of Oil and Chemical Technology, vol.I, Issue 4, ISSN:2326-6589.

Berger, A., Jones P. and Abumweis, S., 2004, Plant sterols: factors affecting their efficacy and safety as functional food ingredients, Lipids in Heallth and Disease, 3(1), 5.

Bora, Pushkar S., Narendra Narain, Rosalynd V.M., Rocha and Marçal Queiroz Paulo, 2001, Characterization of the oils from the pulp and seeds of avocado, (cultivar: Fuerte) fruits, Grasasy Aceites, 52 (3-4), 171-174.

Budhikarjono, Kusno, 1996, “ Diktat Kuliah Alat Industri Kimia”, edisi pertama, pp. 99 - 101, Institut Sepuluh Nopember, Surabaya.

Gracefruit Ltd. "Certificate of Analysis". Gracefruit.com. https://www.gracefruit.com/uploads/attachments/product/158/organicavocado-oil-cofa-lot-kmo2386.pdf (diakses 19 Januari 2019).

Gusviputri, A., Njoo Meliana P. S., Aylianawati., Indraswati, Nani. 2013. Pembuatan Sabun Lidah Buaya (Aloe Vera) Sebagai Antiseptik Alami. Widya Teknik Vol.12, No.1, 11-21.

Hernani., Bunasor, T.K., dan Fitriati, 2010, Formula Sabun Transparan Anti Jamur Dengan Bahan Aktif Ekstrak Lengkuas (Alpinia galanga L.Swartz.), Bul. Litro, 21 (2), 192-205.

Kalia, V.C., Lal, Sadhana. and Rashmi, 2002, Modified cold percolation method for extracting oil from oil seeds, Journal of Scientific and Industrial Research, 61, 630-634. 
Ketaren, S. 1986. Pengantar Teknologi Minyak dan Lemak Pangan. Cetakan Pertama. Jakarta: UI-Press.

Litz, R. E., Raharjo, S.H. T. and Gómez-Lim, M. A., 2007, Avocado. In V. E. C. Pua, \& M. R. Davey (Eds.), Biotechnology in Agriculture and Forestry, Springer-Verlag, Berlin.

Mostert, M.E., Botha, B.M., Du Plessis, L.M. and Duodu, K.G., 2007, Short communication effect of fruit ripeness \& method of fruit drying on the extractability of avocado oil with hexane and supercritical $\mathrm{CO} 2$, Journal of Sciences, Food and Agriculture, 87,2880-2885.

Miller, Kathy. 2003. Miller's Homemade Soap Pages: Choosing Your Oils, Oil Properties of Fatty Acid, (online), (http://www.millersoap.com/soapdesign.html, diunduh 19 Desember 2018).

Mittelbach M dan C Remschmidt. 2006. Biodiesel The Comprehensive Handbook. Ed ke3. Austria: Martin Mittelbach Publisher. Am Blumenhang.

Qisti, R., 2009, Sifat Kimia Sabun Transparan Dengan Penambahan Madu Pada Konsetrasi Yang Berbeda, Skripsi, Fakultas Peternakan, Institut Pertanian Bogor, Bogor.

Requejo, A.M., Ortega, R.M., Robles, F., Navia, B., Faci, M. and Aparicio, A., 2003, Influence of nutrition on cognitive function in a group of elderly, independently living people, European Journal of Clinical Nutrition, 57, S54-S57.

Saputra, Hendra., Nazir, Novizar., dan Sylvi, Diana., 2013, Ekstraksi dan Karakterisasi Minyak Alpukat (Persea Americana, Mill) Solok, Jurnal Teknologi Industri Pertanian, Padang.

Sari, I.,Evi, H., Amelia, T..2010. Pembuatan VCO dengan Metode Enzimatis dan Konversinya Menjadi Sabun Padat Transparan. Jurnal Teknik Kimia, No. 3, Vol. 17, Agsutus 2010.Jurusan Teknik Kimia Fakultas Teknik Universitas Sriwijaya.

SNI 06-3532-1994, Standar Mutu Sabun Mandi, Dewan Standardisasi Nasional, Jakarta.

Seidel, V. 2012. Initial and bulk extraction of natural product isolation. In S.D. Sarker \& L. Nahar (eds). Natural Product Isolation, Methods in Molecular Biology. 864: $27-41$.

Steve. 2008. Saponification Table Plus The Characteristics of Oils in Soap USA, (online), (http://www.soap-making-resource.com/saponification-table.html, diunduh 19 Desember 2018).

Sella, 2013. Analisis Pengawet Natrium Benzoat dan Pewarna Rhodamin B pada Saus Tomat J dari Pasar Tradisional L Kota Blitar. Jurnal Ilmiah Mahasiswa Universitas Surbaya, Vol. 2. No.2.http://repository.ubaya.ac.id. Diakses 19 Desember 2018.

Takenaga, F., Matsuyama, K., Abe, S., Torri, Y. and Itoh, S., 2008, Lipid and fatty acid composition of mesocarp and seed of avocado fruits harvested at Northern range in Japan, Journal of Oleo Science, 57, 591-597. 
Seidel, V. 2012. Initial and bulk extraction of natural product isolation. In S.D. Sarker \& L. Nahar (eds). Natural Product Isolation, Methods in Molecular Biology. 864: $27-41$.

Steve. 2008. Saponification Table Plus The Characteristics of Oils in Soap USA, (online), (http://www.soap-making-resource.com/saponification-table.html, diunduh 19 Desember 2018).

White, P.J. and Armstrong, L.S., 1986, Effect of selected oat sterols on the deterioration of heated soybean oil, Journal of the American Oil Chemists' Society, 84, 10231030.

Winarno, F.G. 2004. Kimia Pangan dan Gizi. Gramedia Pustaka Utama. Jakarta.

Zulharmita., Afrina, Reni., dan Wahyuni, Rina., 2013, Ekstraksi Asam Lemak dari Daging Buah Alpukat, Jurnal Farmasi Higea, Vol. 5, No. 1, 2013. 